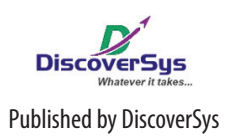

Published by DiscoverSys

\title{
Determinants of long-acting contraceptives use among reproductive-age couples in Tanjung Karang Public Health Centre Mataram City, West Nusa Tenggara
}

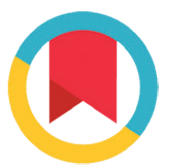

CrossMark

\author{
Widya Aryati, ${ }^{1 *}$ Dewa Nyoman Wirawan, ${ }^{2}$ Komang Ayu Kartika Sari, ${ }^{2}$ \\ Anak Agung Sagung Sawitri ${ }^{2}$
}

\section{ABSTRACT}

Background and purpose: The national family planning program prioritises the use of long-acting contraceptives which include intrauterine devices (IUD), tubectomy, vasectomy, and implant. However, the coverage of long-acting contraceptives in Indonesia remains low. This study aims to identify the determinants of longacting contraceptives uptake among reproductive-age couples in Tanjung Karang Public Health Centre (PHC) Mataram City.

Methods: A cross-sectional study was conducted involving 169 reproductive age couples in Tanjung Karang PHC in 2016. Samples were selected from six sub-villages (dusun) in two villages using systematic random sampling. We selected 85 samples from coastal and 84 samples from non-coastal areas. Data on sociodemographic characteristics, perception, husband support, access to service, and information regarding long-acting contraceptives were collected through home interview. Analysis with logistic regression was applied to determine the factors influencing long-acting contraceptives uptake.
Results: The majority of respondents aged $20-35$ years-old, and most of them have a lower level of education and knowledge regarding longacting contraceptives. Among all current users, as many as $37.0 \%$ use long-acting contraceptive methods. The respondents refused to use long-acting contraceptives due to prohibited by the husband (92.8\%) and desire to have more children (38.7\%). Multivariate analysis using logistic regression showed that the uptake of long-acting contraceptives was significantly associated with area of residence (noncoastal) with an adjusted odds ratio (AOR) $=2.89(95 \% \mathrm{Cl} ; 1.39-6.01)$, employment status with $\mathrm{AOR}=0.40(95 \% \mathrm{Cl} ; 0.18-0.90)$, income at minimum wages and above with $\mathrm{AOR}=2.47(95 \% \mathrm{Cl} ; 1.16-5.26)$, and husband support with $\mathrm{AOR}=2.19$ (95\%Cl; 1.18-3.41).

Conclusions: The use of long-acting contraceptives are associated with husband support, living in non-coastal areas, and having a higherincome. Ongoing support from the husband, especially among those who live in coastal areas and from the lower socioeconomic background, is required to improve the coverage of long-acting contraceptives.
${ }^{1}$ Mataram Health Office, ${ }^{2}$ Public Health and Preventive Medicine Department Faculty of Medicine Udayana University

*Correspondence to: Widya Aryati, Mataram Health Office, widyaayub17975@gmail.com
Keywords: Long-acting contraceptives, determinants, husband support, Mataram.

Cite This Article: Aryati, W., Wirawan, D.N., Sari, K.A.K., Sawitri, A.A.S. 2018. Determinants of long-acting contraceptives use among reproductiveage couples in Tanjung Karang Public Health Centre Mataram City, West Nusa Tenggara. Public Health and Preventive Medicine Archive 6(1): 10-16. D01:10.15562/phpma.v6i1.3

\section{INTRODUCTION}

Based on the 2010 census, the total population of Indonesia was 237.6 million with an average population growth of $1.49 \% .^{1}$ The national government promotes access to quality family planning programs especially long-acting contraceptives which include IUD, tubectomy, vasectomy, and implant to reduce population growth. ${ }^{2}$

The current use of long-acting contraceptives in Indonesia remains low. In West Nusa Tenggara, the uptake of long-acting contraceptives among reproductive-age couples is only $10.6 \%,{ }^{3}$ and the proportion of long-acting contraceptives among current users is $19.2 \% .^{3}$ The coverage of long-acting contraceptives in Mataram City, the capital of West Nusa Tenggara Province, is lower compared to other districts across West Nusa Tenggara, especially in coastal areas. ${ }^{4}$ Reports from 11 public health centres (PHCs) in Mataram City in 2015 revealed that the prevalence of long-acting contraceptives in Tanjung Karang PHC was lower than other PHCs. The current users of long-acting contraceptives were 17,643 (32.9\%), while 35,992 (67.1\%) used short-term contraceptives. ${ }^{5}$ Tanjung Karang PHC serves both coastal and non-coastal areas. The prevalence of long-acting contraceptives is assumed to be lower in coastal areas.

Studies on determinants of long-acting contraceptives uptake in Indonesia and other countries show varied results. The association between several sociodemographic factors and the use of long-acting contraceptives is still inconsistent regarding age, ${ }^{6,7}$ occupation, ${ }^{8,9}$ income, ${ }^{10,11}$ and level of knowledge. ${ }^{10,12}$ However, studies have found a consistent association between the use of 
long-acting contraceptives with education (above junior high) $)^{10,13}$ and low parity. ${ }^{6,10}$ Other studies found that access to health facility influences the use of long-acting contraceptives. ${ }^{11,14}$ In addition, studies have found that myths and misconceptions around long-acting contraceptives including the side effects reduce the overall uptake of long-acting contraceptives. ${ }^{14,15}$ One study reported the relationship between the area of residence and the uptake of long-acting contraceptives. ${ }^{3}$ Furthermore, studies reported inconsistent findings on the relationship between the uptake of long-acting contraceptives with husband support ${ }^{11,15}$ and exposure to information regarding family planning program. ${ }^{10,16}$ Studies in West Nusa Tenggara largely focus among younger married women and have found that the uptake of long-acting contraceptives is influenced by the level of knowledge, information from health providers, and husband support. ${ }^{17}$ Our study aims to compare the use of long-acting contraceptives in coastal and non-coastal areas and to examine determinants of long-acting contraceptives uptake among reproductive-age couples in Mataram City.

\section{METHODS}

A cross-sectional study was conducted in Tanjung Karang PHC in Mataram City, West Nusa Tenggara. There are six villages under the jurisdiction of Tanjung Karang PHC. Four villages are located in coastal areas while the other two are non-coastal areas. One village was selected from the coastal and non-coastal areas. Three sub-villages (dusun) were randomly selected from each village. A total of 169 samples were recruited through systematic random sampling consisted of 85 samples from coastal and 84 samples from non-coastal areas. Our sampling frame involved of 1,400 reproductive-age couples. This sampling frame was developed based on the reproductive-age couple register of six sub-villages (dusun) provided by family planning cadres.

Our respondents were married reproductive aged women who ever used or currently using a contraceptive. Data were collected from June to July 2017 through home interviews. PRECEDE-PROCEED and Health Belief Model were employed in developing a framework to identify determinants associated with the uptake of long-acting contraceptives. The study variables were age, education, occupation, income, knowledge about long-acting contraceptives, perception, parity, the area of residence, access to service, exposure to family planning information, and husband support. Age was categorized into healthy reproductive age (20-35 years-old) and at-risk group $(<20$ and $>35$ years-old). Family income was classified into two categories based on the 2016 minimum wages for Mataram City (IDR 1,714,216). Knowledge about long-acting contraceptives was assessed using 17 questions which included types, application, benefits, and side effects. Every correct answer was scored one, and zero for an incorrect answer. Level of knowledge was classified into good and poor using the cut-off $50 \%$. The perceived susceptibility was assessed using a question about the risk of multiple pregnancies $(>5)$ if not using long-acting contraceptives with three options/responses which the respondent can choose. The perceived susceptibility was classified into high (score $\geq 2$ ) and low $($ score $=1)$. Perceived severity was assessed using three questions about the impacts if the mother does not use long-acting contraceptives. Perceived severity was classified into high (score $>3$ ) and low (score $\leq 3)$. Perceived benefit was assessed using four questions regarding the positive impacts of using long-acting contraceptives. Perceived benefit was classified into high (score $>4$ ) and low (score $\leq 4$ ). Perceived barrier included prohibition from husband to use long-acting contraceptives as well as reluctant to use long-acting contraceptives due to fear of side effects and application methods. Husband support was measured using four questions which included permission to use long-acting contraceptives; husband accompanied the wife to the health service; husband provided information regarding long-acting contraceptives; and husband participation in long-acting contraceptives (vasectomy). Husband support was classified into strong $(\geq 3)$ and weak $(\leq 2)$. Exposure to information regarding family planning from health providers was classified into ever and never received.

Data were analysed using STATA SE 12.1. Logistic regression was used to identify determinants of long-acting contraceptives uptake. The study protocol has been approved by the Human Research Ethics Committee Faculty of Medicine Mataram University on $4^{\text {th }}$ April 2017.

\section{RESULTS}

All participants agreed to participate in our study, and we interviewed 169 respondents at their house. Table 1 presents the characteristics of our respondents. Reproductive age couples who never used contraceptives were excluded. The majority of respondents were current users $(92.9 \%)$ while the rest were ever users (7.1\%). Furthermore, the majority of respondents aged 20-35 years-old, unemployed, with low education level (junior high 
Table 1 Contraceptives use and sociodemographic characteristics among ever and current contraceptive users by the area of residence

\begin{tabular}{|c|c|c|c|c|c|c|}
\hline \multirow[b]{3}{*}{ Variables } & \multicolumn{4}{|c|}{ Area of residence } & & \\
\hline & \multicolumn{2}{|c|}{ Non-coastal } & \multicolumn{2}{|c|}{ Coastal } & \multicolumn{2}{|c|}{ Total } \\
\hline & $\mathbf{n}$ & $\%$ & $\mathbf{n}$ & $\%$ & $\mathbf{n}$ & $\%$ \\
\hline \multicolumn{7}{|l|}{ Contraceptives use } \\
\hline Current user & 82 & 97.61 & 75 & 88.23 & 157 & 92.90 \\
\hline Ever user & 2 & 2.39 & 10 & 11.77 & 12 & 7.10 \\
\hline \multicolumn{7}{|l|}{ Age } \\
\hline$<20$ years & - & 0.00 & 1 & 1.17 & 1 & 0.59 \\
\hline 20-35 years & 60 & 71.42 & 51 & 60.00 & 111 & 65.68 \\
\hline$>35$ years & 24 & 28.58 & 33 & 38.83 & 57 & 33.72 \\
\hline \multicolumn{7}{|l|}{ Employment status } \\
\hline Employed & 36 & 42.85 & 28 & 32.95 & 64 & 37.87 \\
\hline Unemployed & 48 & 57.15 & 57 & 67.05 & 105 & 62.13 \\
\hline \multicolumn{7}{|l|}{ Education } \\
\hline Above junior high school & 28 & 33.33 & 21 & 24.71 & 49 & 29.00 \\
\hline Junior high school and below & 56 & 66.64 & 64 & 75.29 & 120 & 71.00 \\
\hline \multicolumn{7}{|l|}{ Income } \\
\hline At minimum wages and above & 33 & 39.29 & 30 & 35.30 & 63 & 37.28 \\
\hline Below minimum wages & 51 & 60.71 & 55 & 64.70 & 106 & 62.72 \\
\hline \multicolumn{7}{|l|}{ Parity } \\
\hline$\leq 2$ & 40 & 47.62 & 25 & 29.42 & 65 & 38.47 \\
\hline$>2$ & 44 & 52.38 & 60 & 70.58 & 104 & 61.53 \\
\hline \multicolumn{7}{|l|}{ Knowledge } \\
\hline Good & 60 & 71.43 & 30 & 35.30 & 90 & 53.25 \\
\hline Poor & 24 & 28.57 & 55 & 64.70 & 79 & 46.75 \\
\hline Total & 84 & 100.00 & 85 & 100.00 & 169 & 100.00 \\
\hline
\end{tabular}

Table 2 A contraceptive mix between coastal and non-coastal areas (current users)

\begin{tabular}{|c|c|c|c|c|c|c|}
\hline \multirow[b]{3}{*}{ Contraceptive mix } & \multicolumn{4}{|c|}{ Area of residence } & & \\
\hline & \multicolumn{2}{|c|}{ Non-coastal } & \multicolumn{2}{|c|}{ Coastal } & \multicolumn{2}{|c|}{ Total } \\
\hline & $\mathbf{n}$ & $\%$ & $\mathbf{n}$ & $\%$ & $\mathbf{n}$ & $\%$ \\
\hline \multicolumn{7}{|c|}{ Short-acting contraceptives } \\
\hline Injection & 39 & 47.57 & 44 & 58.67 & 83 & 52.87 \\
\hline Condom & 3 & 3.66 & 1 & 1.33 & 4 & 2.54 \\
\hline Pill & 3 & 3.66 & 9 & 12.00 & 12 & 7.65 \\
\hline \multicolumn{7}{|c|}{ Long-acting contraceptives } \\
\hline IUD & 13 & 15.85 & 7 & 9.33 & 20 & 12.73 \\
\hline Implant & 19 & 23.17 & 13 & 17.34 & 32 & 20.39 \\
\hline Tubectomy & 5 & 6.09 & 1 & 1.33 & 6 & 3.82 \\
\hline Vasectomy & - & - & - & - & - & - \\
\hline Total & 82 & 100.00 & 75 & 100.00 & 157 & 100.00 \\
\hline
\end{tabular}




\begin{tabular}{|c|c|c|c|c|c|c|c|}
\hline \multirow[b]{2}{*}{ Variables } & \multicolumn{2}{|c|}{$\begin{array}{l}\text { Long-acting } \\
\text { contraceptives }\end{array}$} & \multicolumn{2}{|c|}{$\begin{array}{l}\text { Short-acting } \\
\text { contraceptives }\end{array}$} & \multirow[b]{2}{*}{ p value } & \multirow[b]{2}{*}{ AOR } & \multirow[b]{2}{*}{$95 \% \mathrm{Cl}$} \\
\hline & $\mathbf{n}$ & $\%$ & $\mathbf{n}$ & $\%$ & & & \\
\hline \multicolumn{8}{|l|}{ Area of residence } \\
\hline Non-coastal & 37 & 44.05 & 47 & 55.95 & \multirow{2}{*}{0.008} & \multirow{2}{*}{2.89} & \multirow{2}{*}{$1.39-6.01$} \\
\hline Coastal & 21 & 24.71 & 64 & 75.29 & & & \\
\hline \multicolumn{8}{|l|}{ Age } \\
\hline$<20$ years & 0 & 0.00 & 1 & 100.00 & \multirow{3}{*}{0.468} & & \\
\hline 20-35 years & 36 & 32.53 & 75 & 67.57 & & & \\
\hline$>35$ years & 22 & 38.60 & 35 & 61.40 & & & \\
\hline \multicolumn{8}{|l|}{ Employment status } \\
\hline Employed & 18 & 28.13 & 46 & 71.88 & \multirow{2}{*}{0.185} & \multirow{2}{*}{0.40} & \multirow{2}{*}{$0.18-0.90$} \\
\hline Unemployed & 40 & 38.10 & 65 & 61.90 & & & \\
\hline \multicolumn{8}{|l|}{ Education level } \\
\hline Above junior high school & 15 & 30.61 & 34 & 69.39 & \multirow{2}{*}{0.516} & & \\
\hline Junior high school and below & 43 & 35.83 & 77 & 64.17 & & & \\
\hline \multicolumn{8}{|l|}{ Income } \\
\hline At minimum wages and above & 28 & 44.44 & 35 & 55.56 & \multirow{2}{*}{0.032} & \multirow{2}{*}{2.47} & \multirow{2}{*}{$1.16-5.26$} \\
\hline Below minimum wages & 30 & 28.30 & 76 & 71.70 & & & \\
\hline \multicolumn{8}{|l|}{ Parity } \\
\hline$\leq 2$ & 16 & 24.62 & 49 & 75.38 & \multirow{2}{*}{0.035} & & \\
\hline$>2$ & 42 & 40.38 & 62 & 59.62 & & & \\
\hline Knowledge & & & & & & & \\
\hline Good & 34 & 44.74 & 42 & 55.26 & 0000 & & \\
\hline Poor & 24 & 25.81 & 69 & 74.19 & 0.009 & & \\
\hline Perceived severity & & & & & & & \\
\hline High & 30 & 36.14 & 53 & 63.86 & 0602 & & \\
\hline Low & 28 & 32.56 & 58 & 67.44 & 0.025 & & \\
\hline Perceived benefit & & & & & & & \\
\hline High & 41 & 37.96 & 67 & 62.04 & 0181 & & \\
\hline Low & 17 & 27.87 & 44 & 72.13 & 0.184 & & \\
\hline Perceived susceptibility & & & & & & & \\
\hline High & 46 & 35.11 & 85 & 64.89 & 0686 & & \\
\hline Low & 12 & 31.58 & 26 & 68.42 & 0.080 & & \\
\hline Exposure to information on fam & & & & & & & \\
\hline Yes & 49 & 35.25 & 90 & 64.75 & 0582 & & \\
\hline No & 9 & 30.00 & 21 & 70.00 & 0.002 & & \\
\hline Access to service & & & & & & & \\
\hline$\leq 1 \mathrm{~km}$ & 48 & 33.57 & 95 & 66.43 & (2000 & & \\
\hline$>1 \mathrm{~km}$ & 10 & 38.46 & 16 & 61.54 & 0.628 & & \\
\hline Husband support & & & & & & & \\
\hline High & 39 & 52.70 & 35 & 47.30 & ( & 1 & 1102 \\
\hline Low & 19 & 20.00 & 76 & 80.00 & 0.000 & 2.19 & $1.18-3.41$ \\
\hline Total & 58 & 34.52 & 111 & 65.68 & & & \\
\hline
\end{tabular}


school or below), earn less than the minimum wages for Mataram City, with parity more than two, and with good knowledge regarding family planning and contraceptives.

Based on area of residence, the use of contraceptives in the coastal was lower than in non-coastal areas. Also, respondents in coastal areas were relatively older and unemployed; had higher parity, lower income and education, and lower knowledge regarding contraceptives when compared to those who live in non-coastal areas.

Table 2 shows the pattern of contraceptives use among current users. Out of 157 respondents who are currently using contraceptives, as many as $63.0 \%$ use short-term contraceptives while $37.0 \%$ use long-term contraceptives. Furthermore, the use of long-acting contraceptives was higher in non-coastal $(45.1 \%)$ than coastal areas $(28.0 \%)$. Vasectomy uptake was $0 \%$. The main reasons for refusing to use long-acting contraceptives were husband prohibition (92.8\%) and desire to have more children (38.7\%).

Table 3 shows the association between the uptake of long-acting contraceptives with predisposing, enabling, and reinforcing factors. All variables with a $\mathrm{p}$-value $<0.25$ in the bivariate analysis were included in the multivariate analysis. These variables were area of residence $(\mathrm{p}<0.008)$, employment status $(\mathrm{p}<0.185)$, family income $(\mathrm{p}<0.032)$, knowledge $(\mathrm{p}<0.009)$, parity $(\mathrm{p}<0.035)$, perceived benefit $(\mathrm{p}<0.184)$, and husband support $(\mathrm{p}<0.000)$.

The multivariate analysis using logistic regression revealed that the uptake of long-acting contraceptives was associated with area of residence (non-coastal areas) with $\mathrm{AOR}=2.89$ (95\%CI: 1.39-6.01); family income at the minimum wages (IDR 1,714,000,-) and above with AOR $=2.47$ (95\%CI: 1.16-5.26), husband support with $\mathrm{AOR}=2.19$ (95\%CI: 1.18-3.41), and employment status with AOR=0.40 (95\%CI: 0.18-0.90).

\section{DISCUSSION}

This study found that the proportion of long-acting contraceptives was $36.9 \%$ among all ever and current contraceptives users. This proportion is higher when compared to the provincial data of West Nusa Tenggara (19.2\%) and the national data $(18.3 \%))^{3}$ The high proportion in our study might be influenced by our sampling strategy. Our samples were selected from the register provided by family planning cadres. Our study also found that the proportion of long-acting contraceptive uptake among current users in non-coastal areas (45.1\%) is higher than in coastal areas (28.0\%). There is limited published literature that examines the uptake of long-acting contraceptives in coastal or non-coastal areas. The majority of existing studies classify the area of residence based on urban or rural areas. The National Demographic and Health Survey in 2012 found that the proportion of long-acting contraceptives uptake was higher in urban than in rural areas. ${ }^{3}$ The high proportion of long-acting contraceptive uptake in non-coastal areas might be associated with some socio-economic characteristics of those who live in non-coastal areas: higher education level (33.3\% vs. $24.7 \%)$, a higher level of knowledge (71.4\% vs. $35.3 \%)$, and higher income (39.3\% vs. $35.3 \%)$.

The present study found that the main barrier to the uptake of IUD and implant was the lack of support from husband. Studies in several cities in Central and West Java found a positive association between husband support and the uptake of long-acting contraceptives. ${ }^{8,10,18}$ Furthermore, studies in Ethiopia also found that conducive discussion between husband and wife was associated with the uptake of long-acting contraceptives. ${ }^{719}$ A study in Central Java documented several barriers to the uptake of long-acting contraceptives which included: fear of side effects or application methods, feeling ashamed as this relates to intimate organs, and availability of services. ${ }^{14}$ Moreover, studies in Uganda and Ethiopia show that perceived barriers might reduce the uptake of long-acting contraceptive among women..$^{20,21}$

Our study found that employed respondents were less likely to use long-acting contraceptives with $\mathrm{AOR}=0.40$ (95\%CI: 0.18-0.90). This finding is consistent with a study in Bogor District West Java which found lower uptake of long-acting contraceptives among employed women (36.9\%) when compared to unemployed women $(47.5 \%)$ though statistically was not significant $(\mathrm{p}=0.184) .{ }^{9}$ However, a case-control study in Pamulang PHC South Tangerang found that employed respondents were more likely to use long-acting contraceptives with $\mathrm{OR}=4.737$ (95\%CI: 2.10-10.69). ${ }^{8}$ Similarly, a cross-sectional study in Kalirejo PHC Negeri Katon Subdistrict, Pesawaran District, Lampung Province found that the use of long-acting contraceptives among employed respondents (47.4\%) was significantly higher than unemployed respondents (7.4\%) $(\mathrm{p}=0.000) .^{22}$

Our study shows that respondents with high family incomes were more likely to use long-acting contraceptives compared to those with low family income with AOR $=2.47$ (95\%CI: 1.165.26). A study in Banten Province also found that high-income respondents were more likely to use long-acting contraceptives with $\mathrm{OR}=2.21$ (95\%CI: 1.08-4.53). ${ }^{8}$ In addition, a study in Banyubiru 
Subdistrict, Semarang City Central Java found that the use of long-acting contraceptive among low-income families $(7.7 \%)$ was significantly lower than wealthy families $(37.4 \%)(\mathrm{p}=0.034) .{ }^{10}$

This study covered only limited areas, and our findings cannot be generalised into wider areas. Only samples from reproductive age couples register that generated by family planning cadres were included, leading to a high proportion of long-acting contraceptives. Therefore, our finding should be interpreted with cautions especially when compared with other studies. Further studies to explore the association between husband support and the uptake of long-acting contraceptives are recommended.

\section{CONCLUSION}

The use of long-acting contraceptives in coastal is lower than in non-coastal areas. The use of long-acting contraceptives is associated with the area of residence (coastal and non-coastal areas), husband support, employment status, and family income. Providing couple education and counselling is an option to improve the uptake of long-acting contraceptives.

\section{ACKNOWLEDGEMENT}

We would like to thank the Head of Tanjung Karang PHC, the Head of Mataram City Health Office, the Head of Women Empowerment and Family Planning Agency Mataram City, and all respondents who have participated in this study.

\section{REFERENCES}

1. National Statistic Bureau. Proyeksi penduduk Indonesia 2010-2035 [The Projection of Indonesia's Population 2010-2035]. 2013.

2. National Demographic and Family Planning Agency. Analisis data kependudukan dan KB hasil Susenas 2015 [An analysis if population data and family planning from the 2015 National Socio-economic Survey]. 2016.

3. National Demographic and Family Planning Agency, National Statistic Bureau, Ministry of Health of Indonesia. Survei Demografi dan Kesehatan Indonesia 2012 [The 2012 National Demographic and Health Survey]. 2013

4. West Nusa Tenggara Provincial Health Office. Profil Kesehatan Provinsi Nusa Tenggara Barat [Health Profile of West Nusa Tenggara Province]. 2015. Mataram

5. Women Empowerment and Family Planning Agency of Mataram City. Laporan tahunan pemberdayaan perempuan dan keluarga berencana [Annual report of women empowerment and family planning agency]. 2015. Mataram
6. Dewi PHC, Notobroto HB. Rendahnya keikutsertaan pengguna metode kontrasepsi jangka panjang pada pasangan usia subur di Polindes Tebalo Kecamatan Manyar Kabupaten Gresik Jawa Timur [Low uptake of long-acting contraceptives among reproductive age couples in Tebalo Health Post, Manyar Subdistrict, Gresik District East Java]. Jurnal Biometrika dan Kependudukan. 2014; 3: 66-72.

7. Gudaynhe SW, Zegeye DT, Asmamaw T, et al. Factors affecting the use of long-acting reversible contraceptive methods among married women in Debre Markos Town, Northwest Ethiopia 2013. Global Journal of Medical Research. E: Gynecology and Obstetrics; 14.

8. Anggraeni P. Determinan penggunaan metode kontrasepsi jangka panjang (MKJP) pada akseptor KB di wilayah kerja Puskesmas Pamulang Tangerang Selatan Provinsi Banten tahun 2014 [Determinants of the use of long acting contraceptives among current users in Pamulang PHC South Tangerang Banten Province in 2014]. Undergraduate Thesis. Universitas Islam Negeri Banten. 2015.

9. Nuryati S, Fitria D. Pengaruh faktor internal dan faktor eksternal terhadap pemilihan alat kontrasepsi pada akseptor KB baru di Kabupaten Bogor Jawa Barat [Influence of internal and external factors on the uptake of contraceptive methods in Bogor District West Java]. Jurnal Ilmu Kesehatan Diagnosis 2014; 5: 632-638.

10. Mahmudah LTN, Indrawati F. Analisis faktor yang berhubungan dengan pemilihan metode kontrasepsi jangka panjang (MKJP) pada akseptor KB wanita di Kecamatan Banyubiru Kabupaten Semarang Provinsi Jawa Tengah [Factors associated with the use of long-acting constraceptives among women in Banyubiru Subdistrict, Semarang City Central Java]. Unnes Journal of Public Health 2015; 2: 76-85.

11. Fienalia RA. Faktor-faktor yang berhubungan dengan penggunaan metode kontrasepsi jangka panjang (MKJP) di wilayah kerja Puskesmas Pancoran Mas Kota Depok Jawa Barat tahun 2011 [Factors associated with the use of long-acting contraceptives in Pancoran Mas PHC Depok City West Java in 2011]. Undergraduate Thesis. Universitas Indonesia Jakarta. 2012.

12. Gebremichael H, Haile F, Dessie A, et al. Acceptance of long acting contraceptive methods and associated factors among women in Mekelle City, Northern Ethiopia. Science Journal of Public Health 2014; 2(4): 349-355

13. Teffera AS, Wondifraw AA. Determinants of long acting contraceptive use among reproductive age women in Ethiopia: Evidence from EDHS 2011. Science Journal of Public Health; 3. 2015: 143-149

14. Christiani C, Diah C, Bambang W. Faktor-faktor yang mempengaruhi pemakaian metode kontrasepsi jangka panjang (MKJP) di Provinsi Jawa Tengah [Factors associated with the use of long acting contraceptives in Central Java]. Serat Acitya-Jurnal Ilmiah 2013; 74-84.

15. Siswanto R, Farich A. Faktor pemilihan metode kontrasepsi jangka panjang (MKJP) pada pasangan usia subur di wilayah kerja Puskesmas Segala Mider Kota Bandar Lampung Provinsi Lampung [Factors associated with the use of long acting contraceptives among reproductive age couples in Segala Mider PHC Bandar Lampung City, Lampung Province]. Jurnal Dunia Kesmas; 4(3): Juli 2015.

16. Alfiah ID. Faktor-faktor yang berhubungan dengan penggunaan metode kontrasepi jangka panjang di wilayah kerja puskesmas Kecamatan Kalideres Jakarta tahun 2015 [Factors associated with the use of long acting contraceptives in Kalideres PHC Jakarta in 2015]. Undergraduate Thesis. Universitas Islam Negeri Syarif Hidayatullah Jakarta. 2015. 
17. Aryanti H, Ani LS, Karmaya NM, et al. Faktor-faktor yang berhubungan dengan penggunan kontrasepsi pada wanita kawin usia dini di Kecamatan Aikmel Kabupaten Lombok Timur Provinsi Nusa Tenggara Barat (NTB) tahun 2014 [Factors associated with the use of contraceptives among early married women in Aikmel Subdistrict East Lombok, West Nusa Tenggara]. Master Thesis. Universitas Udayana Denpasar. 2014

18. Tristanti I, Nasriyah. Hubungan dukungan suami dalam pemilihan metode kontrasepsi jangka panjang (MKJP) di Kudus Provinsi Jawa Tengah [Association between husband support and the use of long acting contraceptives in Kudus District Central Java]. Undergraduate Thesis. Stikes Muhammadiyah Kudus Jawa Tengah. 2016; 183-193.

19. Sahilemichael A. Determinants of long acting reversible contraceptives use among child bearing age women in Dendi District, Western Ethiopia. Journal of Women's Health Care 2015; 4:242.

20. Meskele M, Mekonnen W. Factors affecting women's intention to use long acting and permanent contraceptive methods in Wolaita Zone, Southern Ethiopia: A cross-sectional study. Journal BMC Women's Health 2014; 14:109.
21. Kakaire O, Nakiggude J, Lule JC, et al. Post abortion women's perceptions of utilizing long acting reversible contraceptive methods in Uganda. A qualitative study. Open Journal of Obstetrics Gynecology 2014; 4(4): 1087-1097.

22. Budiarti I, Nuryani DD, Hidayat R. Determinan penggunaan metode kontrasepsi jangka panjang (MKJP) pada akseptor KB [Determinants of long acting contraceptives uptake among current users]. Jurnal Kesehatan 2017; 8(2): 220-224.

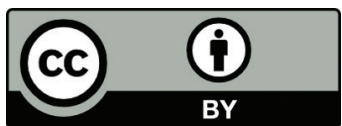

This work is licensed under a Creative Commons Attribution 